\title{
Mentoring in a Catholic High School: The Movement to Receive
}

\author{
Alfred K. M. Pang* \\ Boston College School of Theology \& Ministry
}

This paper explores the dynamics that underlie the process of mentoring high-school students, with Catholic Junior College in Singapore as a site of practice. Using Luke's journey narrative of Jesus' walk with the two disciples to Emmaus (Luke 24:13-35), a Christological framework is proposed that construes the relational practice of mentoring as involving four movements: receiving, blessing, breaking, and giving. Within the limited scope of this paper, the movement of receiving is focused on specifically. The dynamic of receptivity between teacher and student in a mentoring relationship is understood as an extension of God's friendship, incarnated in the practice of fidelity through practical strategies of rapport-building in the classroom. The movement to receive creates a hospitable space of belonging upon which the movements of blessing, breaking and giving are dependent.

\footnotetext{
* Alfred Pang is an M.Ed. student in the School of Theology and Ministry at Boston College. His focus is on Catholic educational leadership, with particular interests in Catholic school identity and mission, as well as practical theology and youth ministry.
} 


\section{Introduction}

As a high school teacher, I am ever fascinated by what young people are thinking about and doing in their lives. While considering the prospect of mentoring as a practice of spiritual formation for my students at Catholic Junior College in Singapore, I decided to ask a student what issues he thought a teacher-mentor should address. This seventeen-year-old remarked that youth at his age should learn how to rationally deal with their personal insecurities, as they are so caught up in their emotional baggage that they have a severe oversight of what they truly want. He also felt that young people are not always honest in speaking about their emotions because of their self-seeking need for approval from others. ${ }^{1}$ Several issues are at once present: emotional vulnerability, a fragile self-esteem that is tied to what one truly wants, and most significantly, a longing for authentic connection and truthful communication. This student is, in psychologist David Elkind's words, "thinking in a new key," which places him in the troublesome spot of making decisions and discriminating between emotions. ${ }^{2}$ He displays an emergent consciousness of choice yet he is struggling to make sense of it.

From the lens of developmental psychology, Sharon Daloz Parks speaks about the selfconsciousness of choice faced by young adults as a journey toward greater self-authorship: "When the locus of authority shifts from assumed authority outside the self to a sense of inner authority, it does so most solidly by moving from dependence upon an assumed Authority to dependence upon authority that is still external-still out there-but that I now choose, because this authority makes sense to me in terms of my observations and lived experience." 3 She argues further for the formation of mentoring communities that "help anchor the vision of the potential self," supporting young adults in their ambivalent transition to fully mature adulthood. ${ }^{4}$

Unfortunately, her discussion is confined to the academy in higher education. ${ }^{5}$ She also mistakenly dismisses the significance of mentoring for students at lower educational levels by claiming that "the young adult (in contrast to the adolescent) does not seek a hero but a mentor.", My student's comments indicate that adolescents are asking equally profound questions about what they truly want, and implicit in this is a yearning for honest discussion about these issues, warranting a place for mentoring in a high-school setting.

This paper explores constructively what mentoring could look like in a Catholic high school, with Catholic Junior College (CJC) as a specific site of practice. First, it will briefly be considered how mentoring is relevant to a vision of Catholic education. Next, I turn to the scriptural narrative of the walk to Emmaus in Luke 24:13-35 to conceive a framework for mentoring as a ministry of faithful accompaniment. Finally, I will focus particularly on how teachers should begin a mentoring relationship with students by first creating a mutual

\footnotetext{
${ }^{1}$ Permission has been granted from this student to reproduce his comments in this paper.

${ }^{2}$ David Elkind, All Grown Up and No Place to Go (Cambridge, MA: Perseus Books, 1998), 25, 49-50.

${ }^{3}$ Sharon Daloz Parks, Big Questions, Worthy Dreams-Mentoring Young Adults in Their Search for Meaning, Purpose, and Faith (San Francisco: Jossey-Bass, 2000), 80.

${ }^{4}$ Ibid., 81.

${ }^{5}$ Ibid.,158-172.

${ }^{6}$ Ibid., 170 .
} 
reciprocity between them through practices of fidelity that incarnate God's friendship in a classroom setting.

\section{Mentoring and the Catholic High School}

According to David F. White, a theologian in youth ministry, educational practices in high schools have been complicit with consumer capitalism in the social construction of 'adolescence' as a preparatory stage of life. Consequently, any given high school "often fails to cultivate young people's range of gifts."7 White's critique resonates with the observable fact that the motive for Singapore's education system to instruct students holistically is rationalized within a paradigm of economic pragmatism. Holistic education is still justified in terms of developing the competencies critical for young people to survive in a global economy in the future. Not to wholly dismiss the value of such pragmatism, but the question certainly arises of how education might be different if youth were valued more for who they are and where they are at in the present instead of what they are to become in the future. What hope can Catholic schools offer in terms of an alternative distinctive vision?

Within CJC, classroom pedagogy and pastoral care have recently been oriented towards developing students' confidence in their future success. However, such efforts are likely to be counter-productive when the very source of their self-doubt and anxiety is rooted in the raised standards of national examinations that are the result of a highly competitive, result-driven educational system. In my mind, what is needed instead on the part of the school as a Catholic institution is to offer an alternative vision of life that exceeds mere survival in the marketplace. Catholic education ought not to merely prepare the young for the workplace, but should awaken in them the sense of a life-giving vocation in love for God and neighbor. It is within this enlarged and more forgiving vision that mentoring assumes relevance in Catholic schools to help young people discover their unique gifted-ness in the complex realities of decision-making. How do we then imagine the shape and form of mentoring for teachers?

\section{Imagining Mentoring through the Walk to Emmaus (Luke 24:13-35)}

This section turns to Luke's narrative of Jesus' walk with the two disciples to Emmaus after his resurrection. What example does Jesus offer to help us understand who a teacher-mentor is and what he or she is about? The purpose here is to draw out from the scriptural text some salient images to underline the constructive principles that would enable us to imagine a Christological approach to mentoring. ${ }^{8}$

\footnotetext{
${ }^{7}$ David F. White, Practicing Discernment with Youth-A Transformative Youth Ministry Approach (Cleveland, Ohio: The Pilgrim Press, 2005), 46.

${ }^{8}$ See Thomas H. Groome, Will There Be Faith?-A New Vision for Educating and Growing Disciples (New York: Harper One, 2011), 39-44. Groome analyzes how the walk to Emmaus is a "paradigm story" that reflects the pedagogy of Jesus, which "[crafts] a teaching/learning event based on life to Faith to life." This essay builds on his
} 
The first image is that of a journey. Luke's account begins by describing the two disciples as "going to a village called Emmaus, about seven miles from Jerusalem" (v. 13, NRSV). For Luke, Jerusalem is not only where the passion of Christ's death and resurrection takes place, but also the very center from which Jesus' disciples are empowered by the Spirit to be "witnesses ... to the ends of the earth" (Acts 1:8). Thus, the two disciples' journey away from Jerusalem to Emmaus may be interpreted as moving away from the center of who they are called to be in Christ. It is only because of the faithful accompaniment of Jesus who "came near and went with them" (v. 15) that the two finally "got up and returned to Jerusalem" (v. 33). Mentoring is thus projected as a ministry of presence in process. The teacher-mentor is invited to be a faithful companion to young people as they (re)-discover their center of meaning and identity.

The second image is that of the stranger. Cleopas infers that Jesus must have been "the only stranger in Jerusalem who does not know the things that have taken place" (v. 18). Jesus as the figure of the stranger symbolizes the mysterious 'other' who confronts the two disciples. Similarly, the art of spiritual mentoring grapples with the other-ness of God that is revealed in the mystery of life shared by the mentor and mentee. As Parks puts it: "Constructive, transforming encounters with otherness and true exchange of ideas are facilitated in mentoring communities, where hospitality to otherness is prized and practiced." ${ }^{\prime 10}$ It was upon the disciples urging Jesus to stay with them that they also recognized him at the breaking of the bread (vv. 2931). In the end, as Jesus "vanished from their sight," the two disciples come to see anew their reality from the place of the other: "Were not our hearts burning within us while he was talking to us on the road, while he was opening the scriptures to us?" (v. 32).

More significantly, the disciples come to see within themselves and in each other the transcendent mystery of Christ, which marks a shift away from their initial objectified view of Jesus as a prophet for themselves, "the one to redeem Israel" (v. 21). Interestingly, this shift corresponds to a developmental change in adolescents from what developmental psychologist Robert Kegan calls a "second order of consciousness" to a third order and beyond-just like the disciples, adolescents are strangely confronted (and often confounded) by the tension felt in the shift from an ego-centric mode of thinking to one that is "cross categorical" and takes into account the values and viewpoints of others. ${ }^{11}$ Kegan emphasizes the need to provide a "holding environment" that supports adolescents in this transition. ${ }^{12}$

Hence, seen through a Christological lens, a mentoring community in the context of a school is that holding space which allows the teacher and student to mutually recognize and negotiate the ways that other-ness revises perspectives outwardly, only to 'come home' to realize their more authentic selves in Christ. Just as Jesus meets the two disciples and draws them into a conversation with him by asking, "what are you discussing with each other while you walk along?" (v. 17), students and teachers together participate in a negotiation grounded in dialogue.

analysis by extending it to the practice of mentoring. In doing so, I am assuming that the art of mentoring is intertwined with teaching.

${ }^{10}$ Parks, Big Questions, Worthy Dreams, 141.

${ }^{11}$ Robert Kegan, In Over Our Heads (Cambridge: Harvard University Press, 1994), 27-28.

12 Ibid., 43. 
The third and final image is the table, which is a pivotal image in Luke's account, since the two disciples recognize Jesus at the breaking of bread when "he was at the table with them" (v. 30). The table is an evocative image for mentoring as a place to belong for communion. Parks makes a similar point in imagining mentoring as the practice of the table, where "you know there will be a place for you, where what is on the table will be shared, and where you will be placed under obligation." "13 This practice of the table is also an interpretive space with a triadic structure-every occasion of spiritual mentoring is never the company of two but a community of three, involving God who initiates, accompanies, and reveals. As theologian Andrew Root notes of this triadic set of relations, "the goal of ministry is not to bring about (healthy or holy) transformation, for this is solely the work of God. The goal is to be faithful to the humanity of the adolescent, seeing him or her as other and transcendent, and committing to be a place-sharer to his or her person." ${ }^{14}$ The table in Luke's narrative metaphorically concretizes mentoring as such a relational ministry of place-sharing.

Now, it strikes me that Jesus' method of accompaniment throughout the journey may be conceived in his Eucharistic action at the table: "When he was at the table with them, he took bread, blessed and broke it, and gave it to them" (v. 30). I propose that Jesus' four movements of receiving, blessing, breaking, and giving are a useful analogy in helping us construct a praxis for mentoring. Broadly, the teacher-mentor welcomes young people by extending to them the friendship of God (receiving), helping them recognize their gifted-ness (blessing), supporting and challenging their beliefs and values (breaking), and empowering them to come to a decision about themselves in loving relationship with others (giving). These four movements interconnect with one another in a dynamic way. Within the remainder of this paper, I will focus on the movement of receiving. The presupposition here is that effective mentoring is shaped crucially by the dynamic of receptivity between the teacher-mentor and student. What is involved in this reception? By what practical strategies can a schoolteacher receive a student when initiating a mentoring relationship?

\section{The Movement to Receive}

The movement to receive is an extension of communion. According to theologian Kenda Creasy Dean, communion is realized by "the practices of holy friendship, starting with the friendship of God in the 'outward and visible sign' of the Eucharist." ${ }^{\text {"It }}$ It striking how Dean's description resonates with what Christ did at the table in the Emmaus story. Teacher-mentors receive their students by extending the friendship of God to them. Such receptivity demands openness between the teacher and student, as well as their mutual openness to God's presence in their lives.

\footnotetext{
${ }^{13}$ Parks, Big Questions, Worthy Dreams, 156.

${ }^{14}$ Andrew Root, Revisiting Relational Youth Ministry-From A Strategy of Influence to A Theology of Incarnation (Downers Grove, Illinois: InterVarsity Press, 2007), 192.

${ }^{17}$ Kenda Creasy Dean, Practicing Passion: Youth and the Quest for a Passionate Church (Grand Rapids, MI: Wm. B. Eerdmans Publishing Company, 2004), 139.
} 
Understandably, the notion of friendship does not always sit comfortably with many teachers, who are in a position of authority. If mentoring is a practice of friendship, can schoolteachers be effective mentors if they are trying to relate to students in the ways their friends treat them? Not wishing to delve into the valid ethical concern of boundary setting, the more important issue for this paper is to clarify what friendship in the context of mentoring means. Friendship in mentoring is not a "covenant of niceness" but a "covenant of truth." ${ }^{\prime \prime}$ In other words, the teacher-mentor in receiving the student is committed to help the young person honor and discern the truth of who he or she is in the way God knows them. Even as this covenant of truth involves a mutual reciprocity between God, teacher-mentor, and student, the manner of relation is also asymmetrical because it is God who always initiates. Furthermore, the teacher-mentor as befriending the young in a mentoring relationship is still a figure of authority, but this authority should be appropriated creatively to empower and not overpower students. In what ways then can teacher-mentors make visible this creative power to incarnate the friendship of God to young people?

In his emphasis on holistic faith formation, Thomas Groome proposes that we "educate for Christian faith as a way of the head, a way of the heart, and a way of the hands." ${ }^{19}$ It seems to me that his conception of the head, heart, and hands as dimensions for Christian religious education could also apply to mentoring. Thus, the movement to receive in a mentoring relationship involves specific habits of the mind, heart, and hands. Of the three, the habits of the heart strike me as the most prominent in this initial movement of receiving as they shape the young person's receptivity to the teacher-mentor. The affective posture of fidelity, in particular, has a significant influence on the student's level of trust and openness. It is in this regard that I consider in greater detail the importance of fidelity and suggest how it may be enacted in practices (habits of hands) that are integrated with classroom teaching. This focus on the heart and hands should not, however, diminish the significance of the habits of the mind, which primarily relate to a mentor's cognitive assessment of context. That is, teacher-mentors recognize that they receive young persons with a specific psychological disposition and worldview shaped by their socio-cultural situations.

\section{Fidelity and its Practices}

Fidelity is a commitment to 'be there' for the young person, which earns her or his trust. Receptivity depends on this trust. In fact, reflecting on the walk to Emmaus, it is because of Jesus' faithful posture of 'sticking with them' throughout the journey that the two disciples finally urged him to stay with them (v. 29). Likewise, teachers must impress upon the hearts of

\footnotetext{
${ }^{18}$ Ibid., 139. Dean attributes the phrase "covenant of niceness" to her colleague Richard R. Osmer. In contrasting the "covenant of niceness" with the "covenant of truth," Dean makes the point that fellowship groups in youth ministry often do not go beyond mere friendliness to a deeper communion based on a committed relationship with God and neighbor. This contrast is also applicable to mentoring in which the friendship between the teacher-mentor and student is rooted in a commitment to God, beyond the niceties of friendliness.

${ }^{19}$ Groome, Will There Be Faith?, 111.
} 
students why they can be approached as mentors in the first place. This reason is provided by teacher-mentors incarnating the fidelity of Christ through an open posture of sincere availability that acknowledges the presence of young people as gift.

The fidelity shown by teacher-mentors is necessarily intertwined with their credibility. As Dean puts it, "for young people, credibility comes in the form of a person who 'gets it'-someone whose concern for the adolescent's well-being translates into sympathy for her worldview, validation of her interests, and acknowledgement of her struggles. ${ }^{20}$ The credibility of teachers as mentors does not only rest on their professional competence in the academic subjects they teach, but also in their manner of relating that exudes a certain longing to connect and be connected. Consequently, mentoring cannot begin without the intentional efforts on the teacher's part to establish rapport with students, creating a mutual sense of belonging. Thus, practices of fidelity include a set of strategies for rapport-building. Below are some strategies that I have used in the classroom.

\section{Create rituals of celebration that affirm young persons as gifts}

I have a ritual of celebrating with students at the beginning and end of each semester with food. My first lesson with a new class always begins with me saying, "I'd like to celebrate my first meeting with you." A jar of chocolates and sweets is then passed around and each student takes one for every personal detail he or she voluntarily offers in a round of self-introduction. I also tell them that no matter how many sweets each decides to take, everybody in the class must have one. This is to signal right from the start that we as a class celebrate life together by sharing. I also have another round of 'munchies' at the end of the semester to affirm and acknowledge the hard work that all of us have put in during the course of the term.

Even the mundane and administrative task of distributing college ties and handbooks can be an opportunity for a meaningful ritual. In one of my classes, before distributing these items, I lead a reflection with my students on what they understand of the college's motto-"in Truth and Love"-and how they think it should be lived. This reflection is followed by a small ceremony where I call each student by name to receive the college tie and handbook. Once again, this ritual of initiation is a way for me to affirm our presence together on a journey towards truth and love, grounding it within the larger frame of meaning the school offers in its motto.

\section{Always seek to praise first}

Dean highlights exhortation as a practice of fidelity in engaging with the passion of young people. According to her, "exhortation is the term Paul used (and classical rhetorical tradition used) for the art of 'being there' through the encouragement, admonishment, and truthtelling that guides the moral formation of communities. ${ }^{21}$ Praising is an act of exhortation that

\footnotetext{
${ }^{20}$ Dean, Practicing Passion, 180.

${ }^{21}$ Ibid., 182.
} 
signals to the young person that someone is interested in the goodness of who he or she is. In adopting a posture of praise before guidance, I have found that students usually open their hearts more readily to me, especially in a highly competitive academic culture that tends to generate more (self-)criticism than appreciation. They are also more willing to listen to any critique I may have upon recognizing that I see their value.

\section{Listen faithfully to the heart themes of students}

The receptivity of students towards teacher-mentors depends critically on how well they feel their heart-themes are being listened to. Fidelity demands that teacher-mentors continually 'be present' to heart themes, which are issues that generate a palpable affective response from young people. ${ }^{22}$ The challenge for the teacher-mentor then is to find ways to infuse classroom teaching with opportunities for such heart themes to surface. In my English class, the first essay assigned is a diagnostic tool to gauge the language ability of my students. However, the topic is to be one which they are passionate about or a question/issue that they find engaging or perplexing. I often find it more telling when students actually struggle to name such an issue or even what they are enthusiastic about. I also shape my lessons around these heart themes, including reading materials and videos that explore them in greater depth. Subsequent essay questions might also revolve around these themes. In these ways pedagogical practice and mentoring speak to each other. Such lessons also become the springboard for further one-to-one or group conversations outside the classroom.

\section{Pray for and with students}

Prayer has been the most productive spiritual practice in fostering my connection with students as a teacher-mentor. As Dean notes, "since all communion begins with God's selfcommunication, prayer is also an indispensable practice of spiritual friendship, a basic form of God's self-communicating passion." "23 In prayer, one recognizes God's faithfulness at work. Reception is ultimately the work of God's Spirit who moves the hearts of young people and reveals to them their own authentic being. Thus, prayer "is both intimate and expansive, personal and outward-reaching, a means by which we know and become known-which makes prayer a vital contributor to the teenager's developing identity." 24

The spiritual practice of prayer in mentoring takes place at three levels. First, at the level of personal prayer, I usually pray that my students recognize that they are never alone and that God is with them. I also pray for the grace to receive them as they are, and for the wisdom to know when to speak and listen. Second, the art of conversation with students is also prayer when

\footnotetext{
${ }^{22}$ White, Practicing Discernment with Youth, 98. White defines a heart theme as involving "some expression of emotion and some brief description of context." He has also proposed some useful practical strategies to surface these heart themes from young people in the context of youth ministry.

${ }^{23}$ Dean, Practicing Passion, 238.

${ }^{24}$ Ibid., 239.
} 
I consciously listen to the lead of the Spirit in the words that are spoken or unspoken. When conversing with students, prayer also comes in the form of intermittent pauses. As Parks highlights, "pause is powerful for young adults because it encourages cultivation of the inner life, honors the emerging inner authority of the young adult, and activates the awareness that he or she participates in the motion of life that transcends one's own efforts to manage and control, a reality larger than the scope of one's ego." ${ }^{25}$ It is in the space of the pause that I invite my students to listen in stillness for a word or image that is tugging within. These words and images received become the wellspring for further dialogue. Finally, prayer takes place at the school level through the weekday liturgies and prayer services. These provide an opportunity for the hopes and aspirations of students to be collectively voiced through the practice of intercessory prayers. At all three levels, prayer becomes a concrete expression of solidarity with the concerns of students and a witness of faithful accompaniment on the part of mentors in a school setting.

\section{The Movement to Receive as Related to the Movements of Blessing, Breaking, and Giving}

This paper proposes a Christological framework modeled after the Emmaus story which construes the relational practice of mentoring as involving four movements: receiving, blessing, breaking, and giving. In focusing on receiving, I examined how schoolteachers as mentors receive their students by extending the friendship of God to them as incarnated in the practice of fidelity. Such fidelity creates a hospitable space for students to be seen and heard as persons, which leads to their receptivity of the teacher as a trustworthy adult/mentor they can speak to about their concerns. The suggested strategies for rapport-building as part of the practice of fidelity have also demonstrated the viability and importance of interweaving classroom pedagogy and mentoring practices.

Of course, the movement to receive is inextricably connected to blessing, breaking and giving. All four movements blend into one another and unfold in a dynamic cycle. This blending is evident in how specific strategies proposed for one movement could in fact realize another. For example, the practical suggestion to praise students does not only foster rapport, but also affirms them of their gifted-ness which realizes the movement to bless. Yet, this movement to bless which guides students to recognize and claim God's goodness in themselves and others involves more than just praise. It requires, for instance, dialogical strategies of questioning that orient a young person to re-image themselves positively.

The dynamic of receptivity between the teacher-mentor and students is also particularly significant in its creation of a hospitable space that grounds the efficacy of the latter two movements in the mentoring process. As Parks notes, "a mentoring community offers hospitality to the potential of the emerging self, and it offers access to worthy dreams of self and world." 26 A hospitable space provides a more conducive environment for a mentor and student to

\footnotetext{
${ }^{25}$ Parks, Big Questions, Worthy Dreams, 145-146.

${ }^{26}$ Ibid., 93.
} 
challenge and critique each other's limiting assumptions in the movement of breaking, such that both "are working on the edge of new knowing and possibility." 27 Furthermore, the sense of belonging formed by rapport-building in the movement of receiving could boost a student's confidence to be involved with others in the class or to undertake some community involvement project, hence actualizing the movement of giving. Inter-related yet distinct, the movements of blessing, breaking and giving are contingent on receiving.

\section{Conclusion}

Mentoring is a ministry of faithful presence and accompaniment. In the context of a Catholic high-school, such mentorship guides students to discover their full potential as persons called for a wider mission of service in love for God and neighbor. It challenges them to negotiate complex shifts in their frames of reference, beyond the narrow script of excellence based on economic success to discern a life-giving vocation. Ambiguity is inherent in this process, which could meet resistance from students who want fixed solutions. Yet, learning how to live amid ambiguity is a necessary ability for adulthood that warrants the formative role of teachers as adult mentors to support their students in their journey towards maturity. The importance of teacher-mentors in Catholic schools calls for continued efforts to construct a whole-school approach that systematically develops mentoring as a skilled practice.

${ }^{27}$ Ibid., 130. 